\title{
ДО ПИТАННЯ ПРО БОЙОВУ СТІЙКІСТЬ КОРАБЛІВ (КАТЕРІВ) ВМС УКРАЇНИ ТА Ï ВПЛИВУ НА РЕАЛІЗАЦІЮ ЇХ БОЙОВИХ МОЖЛИВОСТЕЙ
}

На основі аналізу можливостей засобів космічної та повітряної розвідки збройних сил провідних держав світу, Російської Федерації щзодо виявлення кораблів (катерів) та бойових можливостей їх ударних протикорабельних засобів, розроблений науково-методичний апарат розрахунку бойової стійкості кораблів (катерів) ВМС України, яку необхідно обов'язково враховувати на етапі планування бойових дій при оцінці бойових можливостей кораблів (катерів) та їх груп. На иій основі обтрунтовані та запропоновані пропозииї щзодо підвищення бойової стійкості кораблів (катерів) ВМС України.

Ключові слова: бойова стійкість, космічна розвідка, повітряна розвідка, імовірність розвідки, демаскуючі ознаки, щъільність демаскуючих ознак, час ведення розвідки, коефіцієнт бойової стійкості

\section{Вступ}

Постановка проблеми. Бойова стійкість спроможність кораблів (катерів) зберігати боєздатність та застосовувати свої бойові можливості для гарантованого виконання бойового завдання при активній протидії противника [1].

Величина бойової стійкості визначається складом сил та засобів, їх бойовою готовністю, ступенем живучості основних систем, які забезпечують своєчасне розгортання та бойове застосування [1].

3 точки зору західних військових фахівців під бойовою стійкістю (англ. Resiliency) розуміється спроможність здійснювати безперервні дії та витримувати неминучі втрати, зберігаючи свою бойову ефективність.

Аналіз локальних війн та військових конфліктів останнього століття показує, що для досягнення загальної мети бойових дій на морі ефективно застосовувалися засоби космічної, повітряної та інших розвідок $з$ метою виявлення потенційних цілей, видачі по них цілевказівки в реальному масштабі часу та здійснення пуску високоточною зброєю.

3 урахуванням того, що імовірність ураження високоточною зброєю становить близько одиниці, то бойова стійкість кораблів (катерів) протиборчої сторони та їх ордерів була наближена до 0 тому, що вони не мали можливості здійснити хоча б один залп. Тобто, про подальшу бойову стійкість кораблів (катерів) розмова не йшла.

Також, аналіз тактики дій російської армії при здійсненні анексії Криму в 2014 році показав, що всі дії на морі та у повітрі здійснювалися та корегувалися при проведенні повітряної розвідки літаком дальнього радіолокаційного виявлення та управління А-50У, який має можливість виявляти морські цілі на відстані до 400 км на протязі чотирьох годин безперервно та наводити на них літаки з високоточною зброєю в реальному масштабі часу.

Необхідно також зазначити, що аналіз бойових дій у сучасних локальних війнах та військових конфліктах показує, що можливості засобів космічної та повітряної розвідки, ударних повітряних засобів не дозволяють кораблям (катерам) виконувати декілька бойових пусків з однієї бойової позиції, інакше вони будуть виявлені та знищені [2].

Тобто, сьогодні, кажучи про бойову стійкість кораблів (катерів), в першу чергу необхідно брати до уваги їх можливість не дати противнику виявити себе до моменту першого залпу.

Тому, крім раніше відомих факторів, які наведені у [1], бойову стійкість сьогодні визначають наступні:

- ефективне тактичне маскування;

- прихована підготовка до ведення бойових дій

- приховування або зменшення демаскуючих ознак кораблів (катерів);

- введення противника в оману відносно типу та чисельності кораблів (катерів) при підготовці та веденні бойових дій;

- виконання тактичних прийомів 3 метою суттєвого зменшення імовірності викриття своїх сил.

У статті буде розглянутий та запропонований математичний апарат розрахунку імовірності викриття кораблів (катерів) та на цій основі будуть розроблені рекомендації щодо врахування їх бойової стійкості при розрахунку бойових можливостей кораблів (катерів).

\section{Виклад основного матеріалу}

Заходи планування бойових дій на етапі їх підготовки передбачають проведення розрахунків бойових можливостей своїх сил (кораблів і катерів) та 
можливостей противника. На нашу думку, сьогодні, нажаль, при оцінці бойових можливостей кораблів (катерів) напередодні ведення бойових дій, недостатньо уваги приділяється питанню їх реалізації в бою. Тобто, мова йде про реальну оцінку можливостей противника здійснювати протидію, тобто можливостям його виявляти, супроводжувати наші сили та наносити по них удар.

На даний час невідомий науково-методичний апарат, який би дозволяв реально оцінювати (отримувати конкретні значення показників) конкретного противника щодо його розвідувальних можливостей по виявленню та супроводженню кораблів та катерів конкретного класу або проекту. А такий науковометодичний (математичний) апарат потрібний, бо без нього неможливо реально оцінити свого противника. Очевидний факт: противник буде всіляко намагатися виявляти та відслідковувати кораблі (катери) з метою подальшого нанесення по них удару та ïх знищення.

Для того, щоб оцінити можливості противника щодо виявлення своїх кораблів (катерів) необхідно мати математичний апарат їх розрахунку.

3 цією метою пропонується застосувати теорію пошуку об'єктів, яка викладена у [3].

Для розуміння правильності застосування даної теорії при розрахунку бойової стійкості кораблів (катерів) ВМС України коротко зупинимося на іiі суті. Пошук кораблів (катерів) в пунктах базування або в морі - пошукове завдання, яке вирішує ця теорія. А рішення завдань пошуку об'єктів вимагає необхідного наукового апарату. Пошуком можна назвати процес цілеспрямованого обстеження визначеної області простору для виявлення об'єкта, що знаходиться там.

Під виявленням розуміється отримання інформації про місце об'єкту шляхом встановлення з ним прямого енергетичного контакту. Виявлення здійснюється за допомогою засобів виявлення - оптичних, радіолокаційних, гідроакустичних та інших приладів. Одним з шляхів дослідження процесу пошуку являється побудова і аналіз математичних моделей, які відображають об'єктивні закономірності пошуку i дозволяють встановити причиннонаслідковий зв'язок між умовами здійснення пошуку та його результатами.

Об’єкт пошуку володіє двома характерними особливостями:

- його властивості відрізняються від властивостей навколишнього середовища, у якому здійснюється пошук;

- інформація про місце об'єкту і початку пошуку в процесі його виконання носить, як правило, невизначений характер.
Цією невизначеністю і викликані пошукові дії, сутність яких полягає в тому, щоб отримати інформацію про місце об’єкту.

Контрастність об'єкту пошуку на фоні навколишньої середовища створює можливість його виявлення.

Об’єкти пошуку можуть характеризуватися як наявність випромінювання (електромагнітного, акустичного та ін.), так і його відсутністю. У зв'язку з цим робота засобів виявлення грунтується або на фіксуванні сигналу, який відбивається від об'єкту, або на прийомі його власного випромінювання. Тобто, процес пошуку в значній мірі залежить від властивостей об'єкту і особливостей навколишньої середовища. Всі ці питання складають фізичну основу теорії пошуку.

Вибір оптимального способу пошуку оснований на аналізі математичної моделі і зводиться до встановлення параметрів пошуку, які забезпечують рішення пошукового завдання у найкоротший або заданий час при мінімальних затратах пошукових зусиль.

Поряд 3 власне пошуком у теорії пошуку об'єктів розглядається і його різновид - стеження.

Стеження - процес постійного спостереження за виявленим об'єктом, мета його полягає в підтриманні контакту “спостерігач - об'єкт” і його відновлення у випадку втрати.

Імовірність викриття своїх сил, очевидно, залежить від демаскуючих ознак самих кораблів (катерів) та їх ордерів.

Демаскуючі ознаки - це властивості та якості, які притаманні кораблям (катерам), по яких здійснюється їх виявлення (викриття).

Аналіз демаскуючих ознак щодо виявлення кораблів (катерів) дозволяє визначити шляхи їх зменшення з метою покращення їх бойової стійкості.

До демаскуючих ознак кораблів (катерів) різних класів та їх ордерів відносяться наступні:

- конструктивні особливості надводної частини корпусу кораблів (катерів);

- характерний колір кораблів (катерів), якщо він відрізняється від місцевості;

- ознаки діяльності - електромагнітне та інфрачервоне випромінювання, характерні звуки, спалахи вогню, дим та ін.;

- характерний склад ордерів кораблів (катерів) та їх розміщення в ньому, характерні елементи строю між кораблями (катерами);

- характерна швидкість руху кораблів (катерів) на переході морем.

Імовірність розвідування кораблів (катерів) $P_{\text {розв }}$ залежить від ряду факторів, основними 3 яких є: 
$t_{\text {розв }}-$ час ведення розвідки $j$-м засобом розвідки;

$\mu_{j}$ - щільність розвідувальних ознак (демаскуючих факторів) кораблів (катерів) $j$-му засобу розвідки (кількість признаків за одиницю часу);

$P_{{ }_{j}}-$ середньостатистична імовірність виявлення розвідувальних ознак $j$-м засобом розвідки.

За основу розрахунку імовірності розвідування кораблів (катерів) розвідкою противника може бути використана теорія пошуку об'єктів, яка приведена у [3]. У цьому випадку, імовірність розвідування кораблів (катерів) у пунктах базування та при переході морем $P_{\text {розв }}$ може визначатися по формулі [3]:

$$
P_{\text {розв }}=\exp \left(-\sum_{j} \mu_{j} t_{\text {розв }_{j} j} P_{\beta_{j}}\right) .
$$

3 метою введення противника в оману, забезпечення високої бойової стійкості кораблів (катерів) можуть визначатися і облаштуватися оманні кораблі (катери) або проводитись постановки хибних відволікаючих (дезінформуючих) цілей. При цьому, очевидно, що імовірність прийняття $k$-го оманного корабля (катера) за істинний залежить від його правдоподібності - $\gamma_{k}$, тому, можна записати [3]:

$$
P_{\text {розв }}=\frac{\exp \left(-\sum_{j} \mu_{j} t_{\text {розв } j} P_{d_{j}}\right)}{1+\gamma_{k}},
$$

де $k$ - кількість оманних кораблів (катерів), хибних відволікаючих (дезінформуючих) цілей для одного істинного.

Значення $\gamma_{k}$ може змінюватися від 0 до 1 (при $\gamma_{k}=1$ оманний корабель або катер повністю відповідає істинному кораблю або катеру).

Час ведення повітряної або космічної розвідки залежить від часу знаходження носія розвідки у районі базування кораблів (катерів) або переходу морем та від технічних характеристик засобу розвідки.

Наприклад, час ведення космічної радіолокаційної розвідки кораблів (катерів) розвідувальним супутником серії “Лакрос", який знаходиться на геостаціонарній орбіті, рівний часу знаходження супутника на орбіті. Щільність розвідувальних ознак (демаскуючих факторів) кораблів (катерів) залежить від кількості їх розвідувальних ознак (демаскуючих факторів), які можуть бути проявлені за певний час розвідки. Для кораблів (катерів) щільність цих ознак достатньо велика тому, що вони мають, в залежності від проекту, характерні конфігурацію, побудову, розміри, кількість надводних елементів, ознаки діяльності, види ордерів та швидкості на переході морем. За даних умов та при існуючих характеристиках сучасних та перспективних засобів космічної та повітряної розвідки провідних держав світу приховати кораблі (катери) в пунктах базування та на переході їх морем у складі ордерів сьогодні та й у найближчій перспективі практично не можливо. Тому, для зменшення імовірності викриття (розвідування) кораблів (катерів) $P_{\text {розв }}$ необхідно мати багато оманних правдоподібних кораблів (катерів). Для цього необхідні великі фінансові та матеріальні витрати, що сьогодні та у найближчій перспективі, в умовах ресурсних обмежень держави, стає дуже проблематичним.

Інакше, імовірність розвідування кораблів (катерів) існуючими та перспективними засобами розвідки в пунктах базування та при переході їх морем стає близько до 1. Але, бойова стійкість кораблів (катерів) залежить не тільки від їх викриття. Очевидно, вона залежить також і від імовірності ураження зброєю противника $\mathrm{P}_{\text {ураж }}$ (наприклад, імовірності ураження корабля (катера) однією протикорабельною ракетою). Тому, припускаючи, що розвідування кораблів (катерів) та нанесення по них ударів засобами ураження являються незалежними подіями, можна ввести поняття коефіцієнту бойової стійкості, який можна розраховувати за формулою:

$$
K_{б c}=\mathrm{P}_{\text {роз }} \cdot \mathrm{P}_{\text {ураж}} .
$$

3 метою оцінки (розрахунку) реальних бойових можливостей кораблів (катерів) ВМС України та їх угруповань цей коефіцієнт пропонується розраховувати та враховувати в існуючих методиках розрахунку бойових можливостей.

\section{Висновки}

Таким чином, аналіз можливостей засобів розвідки збройних сил провідних держав світу, Російської Федерації показує, що при наявності в їх складі сучасних ефективних космічних, повітряних засобів високоточних протикорабельних ракет, імовірність знищення кораблів (катерів) ВМС України у пунктах базування та на переході морем може бути дуже високою, тобто бойова стійкість кораблів (катерів) є недостатньою для реалізації своїх бойових можливостей та виконання ними поставлених бойових завдань на морі.

3 метою недопущення цього, в умовах ресурсних обмежень держави, необхідно негайно шукати та обгрунтовувати раціональні пропозиції по суттєвому зменшенню щільності розвідувальних ознак (демаскуючих факторів) кораблів (катерів), що може стати темою окремого дослідження. 


\section{Список літератури}

1. Родіонов І.М. Військова енциклопедія / І.М. Родіонов. - М.: Військове видавництво, 1994. - Т. 1. - 328 с.

2. Єрмошин М.О. Боротьба в повітрі / М.О. Єрмошин, В.М. Федай. - Х.: ХВУ, 2004. - 381 с.

3. Абчук В.А. Поиск объектов / В.А. Абчук, В.Г. Суздаль. - М.: Сов. радио, 1977. - 336 с.

4. Посібник. Тактика військово-морських сил. - Одеса: Інститут ВМС. - 2017. - 154 с.

5. Бронштейн І.М. Довідник по математиці / І.М. Бронштейн, К.А. Семендяєв. - М.: Фізматліт, 1955. - 609 с.

6. Смаль А.Г. Военно-морские силы иностранных государств: Справочник / А.Г. Смаль. - М.: Воениздат, 1988. $-863 \mathrm{c}$.

7. Довідник НАТО [Електронний ресурс]. - Брюссель: NATO-1110. - 2001. - 591 с. - Режим доступу: https://www.nato.int/docu/other/ukr/handbook/2001/pdf/handbook.pdf.

8. Гордиенко Ю.В. Военная авиация / Ю.В. Гордиенко, В.П. Морозов, А.С. Прибылов. - Монино: ООО "Попури", 1999. $-82 \mathrm{c}$.

9. Касаткин А. Структура коалиционных органов управления ОВС НАТО [Електронний ресурс] / А. Касаткин // Зарубежное военное обозрение. - 2002 . - № $5 . \quad$ - $\quad$ С. 2-5. - Режим доступу: http://factmil.com/publ/strana/nato/struktura_koalicionnykh_organov_upravlenija_ovs_nato_2002/61-1-0-1606.

10. Довідник з протиповітряної оборони / А.Я. Торопчин, І.О. Романенко, Ю.Г. Даник, Р.Е. Пащенко. - К.: МО України, 2003. - 260 с.

11. Дрожжин А.И. Воздушные войны в Ираке и Югославии / А.И. Дрожжин. - М.: ООО “Восточный горизонт", 2002. $-80 \mathrm{c}$.

12. Жеребилов А.А. Современная военная авиация / А.А. Жеребилов. - Смоленск: Русич, 2000. - 128 с.

13. Шунков В.Н. Авианесущие корабли и морская авиация / В.Н. Шунков. - Монино: ООО “Попури”, 2003. - 588 с.

14. Теорія і техніка протидії безпілотним засобам повітряного нападу: монографія / В.І. Ткаченко, Ю.Г. Даник, Г.А. Дробаха, В.І. Карпенко, Р.Е. Пащенко, С.Б. Смірнов. - Х.: ХВУ, 2002. - 220 с.

\section{References}

1. Rodionov, I.M. (1994), "Viyskova entsyklopediya" [Military Encyclopedia], Viyskove vydavnytstvo, Moscow, 328 p.

2. Yermoshyn, M.O. and Fedai, V.M. (2004), "Borotba v povitri" [Fighting in the air], KhVU, Kharkiv, 381 p.

3. Abchuk, V.A. and Suzdal, V.H. (1977), "Poysk obyektov" [Search for objects], Sov. radyo, Moscow, 336 p.

4. (2017), "Taktyka viiskovo-morskykh syl" [Tactics of the Vijsk-Marine forces], Instytut VMS, Odesa, 154 p.

5. Bronshtein, I.M. and Semendiaiev, K.A. (1955), "Dovidnyk po matematytsi" [Handbook of mathematics], Fizmatlit, Moscow, 609 p.

6. Smal, A.H. (1988), "Voenno-morskye syly ynostrannykh hosudarstv: Spravochnyk" [Naval Forces of Foreign States: A Handbook], Voenyzdat, Moscow, 863 p.

7. (2001), "Dovidnyk NATO" [NATO Handbook], NATO-1110, Brussels, 591 p., available at: www.nato.int/docu/other/ukr/handbook/2001/pdf/handbook.pdf.

8. Hordyenko, Yu.V., Morozov, V.P. and Prybylov, A.S. (1999), "Voennaia avyatsyia. Spravochnyk" [Military aircraft], OOO “ Popury”, Monyno, 82 p.

9. Kasatkyn, A. (2002), "Struktura koalytsyonnykh orhanov upravlenyia OVS NATO" [Structure of NATO OAF coalition governing bodies], Foreign Military Review, No. 5, pp. 2-5, available at: www.factmil.com/publ/strana/nato/struktura_koalicionnykh_organov_upravlenija_ovs_nato_2002/61-1-0-1606.

10. Toropchyn, A.Ya., Romanenko, I.O., Danyk, Yu.H. and Pashchenko, R.E. (2003), "Dovidnyk z protypovitrianoi oborony" [Air Defense Handbook], MO Ukrainy, Kyiv, 260 p.

11. Drozhzhyn, A.Y. (2002), "Vozdushnye voiny v Irake i Yuhoslaviy" [Air Wars in Iraq and Yugoslavia], OOO "Vostochnyi horyzont", Moscow, $80 \mathrm{p}$.

12. Zherebylov, A.A. (2000), "Sovremennaia voennaia avyatsyia" [Modern military aircraft], Rusych, Smolensk, 128 p.

13. Shunkov, V.N. (2003), "Avyanesushchye korably y morskaia avyatsyia" [Carrier ships and naval aviation], OOO "Popury", Monyno, 588 p.

14. Tkachenko, V.I., Danyk, Yu.H., Drobakha, H.A., Karpenko, V.I., Pashchenko, R.E. and Smirnov, Ye.B. (2002), "Teoriia i tekhnika protydii bezpilotnym zasobam povitrianoho napadu" [Theory and technology of protection against the hardships of repeated attack], KhVU, Kharkiv, $220 \mathrm{p}$.

Надійшла до редколегї 04.02.2020

Схвалена до друку 10.03 .2020

\section{Відомості про авторів:}

\section{Корощенко Микола Миколайович}

начальник кафедри

інституту Військово-морських Сил

“Одеської національної морської академіі”,

Одеса, Україна

https://orcid.org/0000-0002-3445-2297

\section{Information about the authors:}

\author{
Mykola Koroshchenko \\ Head of the Department \\ of the Naval Forces Institute \\ of the Odessa National Maritime Academy \\ Odesa, Ukraine \\ https://orcid.org/0000-0002-3445-2297
}




\author{
Харитонов Олександр Леонідович \\ доцент кафедри інституту \\ Військово-морських Сил \\ “Одеської національної морської академіі”, \\ Одеса, Україна \\ https://orcid.org/0000-0002-7285-8001
}

\author{
Oleksandr Kharytonov \\ Associate Professor of Department \\ of the Naval Forces Institute \\ of the Odessa National Maritime Academy, \\ Odesa, Ukraine \\ https://orcid.org/0000-0002-7285-8001
}

\title{
К ВОПРОСУ О БОЕВОЙ СТОЙКОСТИ КОРАБЛЕЙ (КАТЕРОВ) ВОЕННО-МОРСКИХ СИЛ УКРАИНЫ И ЕЕ ВЛИЯНИИ НА РЕАЛИЗАЦИЮ ИХ БОЕВЫХ ВОЗМОЖНОСТЕЙ
}

\author{
Н.Н. Корощенко, А.Л. Харитонов
}

На основе анализа возможностей средств космической и воздушной разведки вооруженных сил ведущих стран мира, Российской Федерации по обнаружению кораблей (катеров) и боевых возможностей их ударных противокорабельных средств разработан научно-методический аппарат расчета боевой стойкости кораблей (катеров) ВМС Украины, которую обязательно необходимо учитывать на этапе планирования боевых действий при оценке боевых возможностей кораблей (катеров) и их групп. На этой основе обоснованы и предложены предложения по повышению боевой стойкости кораблей (катеров) ВМС Украины.

Ключевые слова: боевая стойкость, космическая разведка, воздушная разведка, вероятность разведки, демаскирующие признаки, плотность демаскирующих признаков, время разведки, коэффициент боевой стойкости.

\section{TO THE QUESTION OF THE MILITARY RESISTANCE OF SHIPS (BOATS) OF THE NAVY OF UKRAINE AND ITS INFLUENCE ON THE IMPLEMENTATION OF THEIR MILITARY POSSIBILITIES}

\author{
M. Koroshchenko, O. Kharytonov
}

An analysis of local wars and military conflicts of the last century shows that space, air, and other reconnaissance tools have been effectively deployed to achieve the common goal of offshore combat to identify potential targets, deliver real-time targets, and deliver launching precision weapons. On the basis of the analysis of the capabilities of space and air reconnaissance of the armed forces of the leading powers of the world, the Russian Federation on the detection of ships (boats) and the combat capabilities of their striking anti-ship means, a scientific and methodological apparatus for calculating the combat stability of ships (boats) of the Ukrainian Navy clearly consider the stage of combat planning when assessing the combat capabilities of ships (boats) and their groups. When calculating the combat stability of ships (boats) of the Navy of the Armed Forces of Ukraine it is proposed to enter the coefficient of combat resistance. This coefficient characterizes the ability of ships (boats) to maintain combat capability and to use their combat capabilities to guarantee the performance of a combat task while actively countering the enemy. On this basis, proposals for improving the combat stability of ships (boats) of the Ukrainian Navy are substantiated and proposed. These proposals will improve the combat stability of ships (boats) of the Ukrainian Navy in order to accomplish their assigned missions.

Keywords: combat stability, space exploration, aerial reconnaissance, reconnaissance probability, demo traits, demo trait density, reconnaissance time, combat stability ratio. 